\title{
The Mediterranean Eco-Industrial Development Model
}

\author{
A. Dominici Loprieno, M. Tarantini, R. Preka, and M. Litido
}

\begin{abstract}
Industrial areas are a fundamental element of territorial development, since they can promote growth, jobs and entrepreneurship. Nevertheless the excessive exploitation of raw materials, the use of non-renewable energy resources, the emission of pollutants and waste production have up to now represented a weakness in the present production model. In this context Mediterranean Eco-Industrial Development (MEID) project, funded by the European program MED, aims to define a joint model to plan, build and manage sustainable Industrial Areas in the Mediterranean region, improving sustainable development and SMEs competitiveness. The model intends to enhance capacities and develop decision tools for Competent Authorities and Industrial Area Managers to integrate environmental friendly solutions into the Regional and Interregional Industrial Development Strategies. An incremental approach has been adopted to ensure the model applicability to new industrial areas, as well as already operating non structured and structured areas. Fundamental parts of the management model are high level infrastructures and innovative services to support SMEs to create networks, exploit the eco-innovation opportunities and face the challenges of the Green economy.
\end{abstract}

Index Terms-Industrial development strategies, Mediterranean Region, MEID project, Sustainable Industrial Areas.

\section{INTRODUCTION}

Industrial Areas (IAs) located in Mediterranean countries with a strong manufacturing base have a strategic interest for the territory development. They are often located close to the cities for historical reasons, generally host from a few dozen to several hundred Small and Medium-Sized Enterprises (SMEs), and are rarely managed at area level. They often cause friction with the neighboring population and the Local Authorities, owing to their emissions, the noise and traffic congestion they cause.

Moreover, the unsustainable trend in soil use in several European Regions has increased the political awareness of the problems caused by small and diffused industrial areas. It is now crucial to define a sustainable policy based on a cooperative climate among enterprises, citizen, Local Authorities.

MEID project, funded in the framework of the transnational program of European territorial cooperation

Manuscript received January 10, 2013; revised April 1, 2013. This work was funded by the European Regional Development Fund in the framework of the Cooperation Programme MED. It is lead by ENEA with the support of nine partners from six different countries.

The authors are with ENEA (Italian National Agency for New Technologies, Energy and Sustainable Economic Development), Italy (e-mail: arianna.dominici@enea.it,_mario.tarantini@enea.it, rovena.preka@enea.it, maria.litido@enea.it).
MED, aims to define a joint Mediterranean model to plan, built and manage IAs, improving sustainable development and SMEs competitiveness. The model intends to enhance capacities and develop decision tools for Competent Authorities and Industrial Area Managers to integrate environmental friendly solutions into Regional and Interregional Industrial Development Strategies.

\section{MEID PROJECT}

The three years long MEID project, which started on July 2010, associates ten partners of five Mediterranean countries (Italy, France, Spain, Greece, Malta) and Bosnia-Herzegovina under the leadership of ENEA, the Italian National Agency for New Technologies, Energy and Sustainable Economic Development. Main aim of the project is to reduce environmental impact, harmonize regulations across similar territories, optimize social-welfare gains and sustain SMEs competitiveness. Output of the project is a methodological model to plan, build and manage Sustainable Industrial Areas (SIAs) of Mediterranean Region in a competitive way, improving sustainable development and SMEs competitiveness. In particular, re-launching of IAs, the key drivers of local and regional economic and job growth, can help to improve the competitiveness of Mediterranean territories and overcome the risk of deindustrialization, as well as better control environmental impacts (emissions, traffic congestion) and particularly the unreasonable use of soil due to scattered IAs.

Moreover, promoting networking and collaboration among co-located firms can foster SMEs participation to Green Economy (as suggested, among others, by COM(2012) 173, "Towards a job-rich recovery" [1]) and long term Eco-Industrial Development according to the principles of Industrial Ecology.

\section{MEID MODEL}

\section{A. SWOT Analysis}

SWOT analysis is a strategic planning method used to evaluate the Strengths, Weaknesses, Opportunities and Threats involved in a project or in a business case (Fig. 1). It has been applied in the MEID partner countries to identify the best practices and the critical elements of IAs management in Mediterranean countries.

The SWOT analysis of IAs main characteristics allowed to gather a better comprehension of the ways IAs can improve their situation, solve crucial points and develop new strategies towards sustainability. In the MEID project, the analysis has concerned the three pillars of sustainability: environment, economy and society. 


\begin{tabular}{|c|c|c|c|}
\hline \multirow{2}{*}{\multicolumn{2}{|c|}{ SWOT ANALYSIS }} & \multicolumn{2}{|c|}{ Internal analysis } \\
\hline & & Strengths & Weaknesses \\
\hline \multirow{2}{*}{ 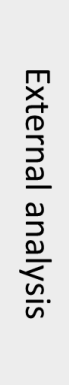 } & Opportunities & $\begin{array}{l}\text { How do I use these } \\
\text { strengths to take } \\
\text { advantage of these } \\
\text { opportunities? }\end{array}$ & $\begin{array}{l}\text { How do I overcome } \\
\text { the weaknesses } \\
\text { that prevent me } \\
\text { taking advantage of } \\
\text { these } \\
\text { opportunities? }\end{array}$ \\
\hline & Threats & $\begin{array}{l}\text { How do I use my } \\
\text { strengths to reduce } \\
\text { the likelihood and } \\
\text { impacts of these } \\
\text { threats? }\end{array}$ & $\begin{array}{l}\text { How do I overcome } \\
\text { these weaknesses } \\
\text { that will make } \\
\text { these threats a } \\
\text { reality? }\end{array}$ \\
\hline
\end{tabular}

Fig. 1. SWOT analysis

The information needed for the SWOT analysis have been gathered by questionnaires sent to the best managed areas in the MEID partners countries. The elements which emerged as valuable requirements of a successful SIA have been kept, systematized and reinforced to define the MEID model. Besides, that management model has been built on the findings of the LIFE project SIAM (Sustainable Industrial Area Model) concluded in 2007 and coordinated by ENEA [2].

\section{B. Application Steps of MEID model}

The MEID model is to be intended as a series of necessary steps to be followed to implement a sustainable management of Mediterranean IAs. Since the investigated areas have different levels of management and a large variability of characteristics, three different paths to reach a sustainable management have been detected, to be followed on the basis of the starting point of the IA. An incremental approach has been adopted to ensure the model applicability to new, as well as already operating non structured and structured IAs.

1) Path 1: planning and design of new IAs

The first path aims at describing the steps to be followed by an IA in the planning and design phases which wants to progress towards sustainability following the requisites of the MEID Model.

\section{2) Path 2: towards MEID model in non structured IAs}

The second path of the MEID procedure describes the steps of a non structured IA (which are the vast majority in the Mediterranean area) to be qualified as sustainable following the MEID model (Fig. 2).

\section{3) Path 3: MEID model in structured IAs}

Fig. 3 represents the key elements of the MEID management model in structured IAs. In this case a more structured and formalized approach has to be followed.

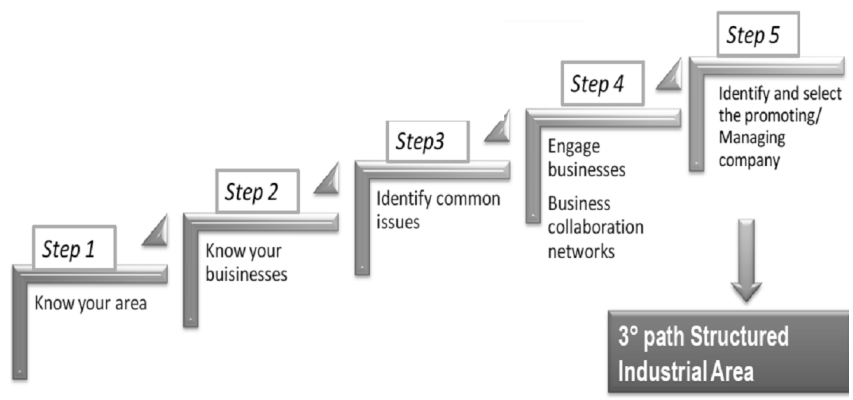

Fig. 2. Towards MEID model in non structured IAs

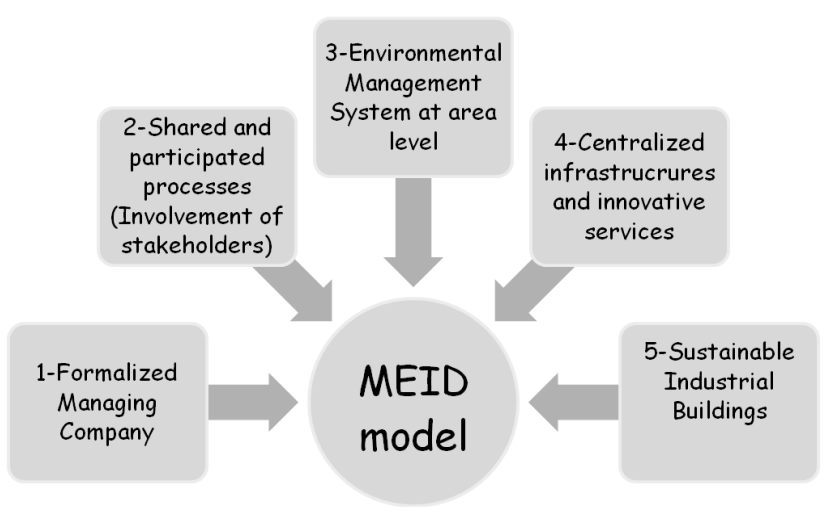

Fig. 3. The MEID management model

As MEID project is still in progress, the model is being tested in three selected pilot areas located in the Mediterranean regions, which are also partners of the project: Ragusa (Italy), Padova (Italy) and Valencia (Spain) (Fig. 4). According to their stage of development and depending on whether they are new or already existing ones, the MEID managing model will be differently experienced.

In the following paragraphs the main elements of the MEID model are shown.

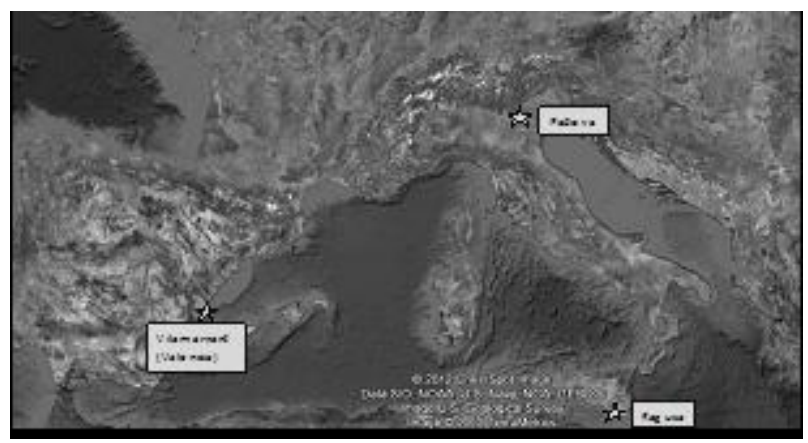

Fig. 4. MEID pilot Industrial Areas

\section{Elements of the MEID Model}

\section{1) Formalized Managing Company}

Essential element of the MEID model is the presence of a Managing Company (MC), whose functions are decisive for the area development. The SWOT analysis, in fact, has highlighted that all the examined areas which adopted one or more good practices have a Managing Company, characterized by different functions and dimensions.

The process of conversion to SIAs can be boosted by adopting a common area management system leaded by the $\mathrm{MC}$, supporting the settled companies to act as a community, using the opportunities offered by the shared area services and infrastructures and collaborating with Local Authorities to define voluntary agreements and action plans aiming at the improvement of the economic, environmental and social performances of the area. This approach is also fundamental in the context of Industrial Ecology and Eco-industrial Parks (EIPs). An EIP, in fact, is defined as a community of companies that must manage itself to provide benefits for its members; it is characterized by an EIP management that fills many of the traditional roles of an industrial park manager, while also maintaining a relationship with the EIP members similar to the relationship between a company and its branch 
plants. The EIP management unit adds value to the production and service functions of its members by performing different roles [3].

To better perform its tasks, the MC should represent the settled firms and be responsible of its performances and institutional relations. It should define the rules of the functioning of the industrial area and guarantee their implementation. It also functions as interface with the Local Authorities and stakeholders and can improve connections between the companies and the world of research and qualified consultancy.

\section{2) Shared and participated processes}

The involvement of public and private stakeholders in the management decisions of a SIA is a fundamental step of the model (Fig. 5). If the MC is a private organization, the connections with Local Authorities and local reference system should be particularly improved to reach a shared vision and gain a wide consensus over the area industrial policy. The objectives of improvement of a SIA could be easily ensured by involving the resident companies, Local Authorities, category and industrial associations, energy, water and waste management companies, trade unions in a Local Committee which helps in identifying the weak points and the improvement action of the area. As resulted from the SWOT analysis, the role of the Local Authorities as facilitators for the sustainable objectives of IAs is mostly connected to the administrative and regulation relief, rather than to financial incentives who still, remain important.

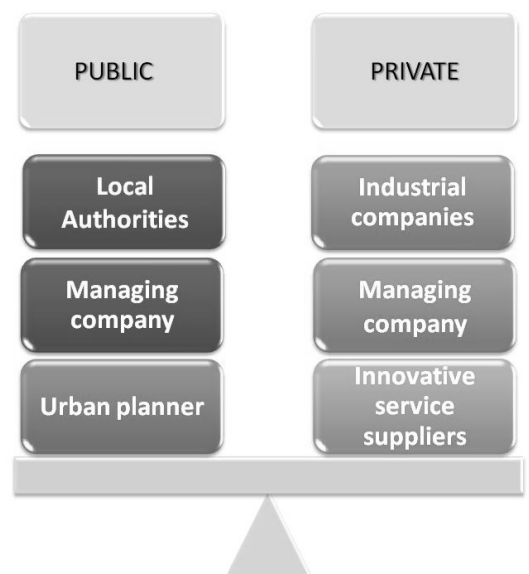

Fig. 5. The basis of the MEID management model: a correct equilibrium among public and private interests

\section{3) Environmental Management System at area level}

Industrial areas should adopt an Environmental Management System such Environmental Management and Audit Scheme (EMAS) or ISO 14001. They require that an Environmental Policy, a Monitoring Plan, an Improvement Plan and a Communication Procedure should be implemented through the following steps:

- definition of the IA policy and the macro objectives of sustainability;

- analysis of the environmental aspects and detection of the significant ones;

- definition of a shared improvement plan;

- implementation of a system to monitor the environmental performance of the IA;
- definition of the procedures for the internal/external communication.

4) Centralized infrastructures and innovative services

Fundamental parts of the management model are high level infrastructures and innovative services to support SMEs to create networks, exploit the eco-innovation opportunities and face the challenges of the Green Economy. SIAs should have shared plants and networks of services and infrastructures for the management of environmental, economic and social aspects. The common infrastructures and innovative centralized services could be managed directly, or through third parts, by the MC which, in any case, will have to guarantee the quality of the delivered services.

In the MEID project a database of Best Practices in the IAs of the Mediterranean Region has been created [4] and is accessible on-line. This database includes examples of techniques, technologies and best practices which improve the environmental, social or economic performance of the areas located in the MEID partners countries (Fig. 6). The description of the Best Practices can be downloaded from the relative folder. An essential bibliography about best practices on Industrial Areas called "Document Repository" is also included.

\begin{tabular}{|c|c|c|}
\hline \multicolumn{2}{|r|}{ Environmental Best Practices } & $\begin{array}{l}\text { No. of } \\
\text { areas }\end{array}$ \\
\hline \multirow[t]{2}{*}{ Waste } & Door-to-door waste collection & 4 \\
\hline & Material recovery plant & 3 \\
\hline \multirow[t]{2}{*}{ Mobility } & Car pooling or car sharing & 4 \\
\hline & Bikeway & 3 \\
\hline \multirow[t]{2}{*}{ Energy } & Energy recovery plant using biomass & 5 \\
\hline & $\begin{array}{l}\text { Photocell panels (for illumination plant or production of } \\
\text { electricity) }\end{array}$ & 4 \\
\hline \multirow[t]{2}{*}{ Water } & $\begin{array}{l}\text { Wastewater treatment plant or Recycling of discharged } \\
\text { water }\end{array}$ & 19 \\
\hline & Rainwater collection & 4 \\
\hline \multirow[t]{2}{*}{$\begin{array}{l}\text { Environmental } \\
\text { monitoring }\end{array}$} & Environmental monitoring of the area & 5 \\
\hline & Social Best Practices & $\begin{array}{l}\text { No. of } \\
\text { areas }\end{array}$ \\
\hline \multicolumn{2}{|c|}{ Inter-company nursery } & 5 \\
\hline \multicolumn{2}{|c|}{ Fibre optics and/or Wi-Fi telematic network } & 5 \\
\hline \multicolumn{2}{|c|}{ Services centre (post offices, banks, hotel, restaurants, superettes, ...) } & 4 \\
\hline \multicolumn{2}{|c|}{ Roads (motorway, railway) } & 4 \\
\hline \multicolumn{2}{|c|}{ Food services (restaurant, cafeteria, area canteen, ...) } & 10 \\
\hline \multicolumn{2}{|c|}{ Hotels and accommodations } & 3 \\
\hline
\end{tabular}

Fig. 6. Best practices of MEID database

\section{5) Sustainable Industrial Buildings}

Among the industrial areas infrastructures, industrial buildings are particularly relevant. Construction is, in fact, one of the sectors with higher environmental impact at European level, also in the Mediterranean area.

During the last years, the norms related to construction sector are continuously being updated, in order to get a better environmental behavior of buildings. However, there is a strong interest, from the developers to the final users of the buildings, to go further than the normative requirements and pursue environmental excellence as an achievable goal.

In the MEID project a "MEID Guide for the construction of environmentally sustainable industrial buildings" has been developed. It is an adaptation of the "Guía de edificación sostenible - Edificios industriales" elaborated by the Basque Government, particularly by Ihobe (Basque Environmental Protection Agency) and Sprilur (Basque Public Industrial 
Management Agency) [5]. The Guide describes a wide list (88 measures) of good practices applicable to the construction of industrial buildings and sites throughout all their lifecycle. It covers construction materials, as well as the construction process and issues related to energy consumption and other natural resources that are associated to the use of the building. All the areas of environmental actions are shown in Fig. 7.

Aim of the Guide is to present a series of recommendations to the different agents implied in the process of design, construction and maintenance to ensure that this is undertaken under an environmentally sustainable perspective.

The Guide contains a series of checklists indicating measures that can vastly improve the building sustainability. Each of the proposed measures has more or less impact on one or several areas of action and, consequently, has been assigned a score on a scale of $0-5$. A weighting system allows to get a unique final score for the entire building.

\begin{tabular}{|c|}
\hline $\begin{array}{l}\text { Materials: Weight }=0.23 \\
\text { Reduced consumption of non-ren. raw } \\
\text { materials }\end{array}$ \\
\hline $\begin{array}{l}\text { Energy: } \quad \text { Weight }=0.31 \\
\text { Reduced use of non renw. energy }\end{array}$ \\
\hline $\begin{array}{l}\text { Indoor environment: Weight }=0.01 \\
\text { Improved quality of interior air, } \\
\text { comfort and health }\end{array}$ \\
\hline $\begin{array}{l}\text { Air: Weight }=0.03 \\
\text { Reduced emission of gases, dust, heat } \\
\text { and luminous energy }\end{array}$ \\
\hline $\begin{array}{l}\text { Waste: } \quad \text { Weight }=0.08 \\
\text { Reduced generation of solid waste }\end{array}$ \\
\hline
\end{tabular}

\begin{tabular}{l}
$\begin{array}{l}\text { Drinking water: Weight }=0.03 \\
\text { Reduced consumption of drinking water }\end{array}$ \\
$\begin{array}{l}\text { Grey water: Weight }=0.05 \\
\text { Reduced generation of greywater }\end{array}$ \\
$\begin{array}{l}\text { Land use: Weight }=0.02 \\
\text { Reduced land occupation }\end{array}$ \\
$\begin{array}{l}\text { Mobility and Transport: Weight }=0.13 \\
\text { Reduced transport processes and } \\
\text { improved personal mobility }\end{array}$ \\
$\begin{array}{l}\text { Ecosystems: Weight }=0.11 \\
\text { Improved operation of natural areas and } \\
\text { increased biodiversity }\end{array}$ \\
\hline
\end{tabular}

Fig. 7. Areas of environmental actions of the MEID Guide for sustainable industrial building

\section{Network of Enterprises}

The establishment of a network of enterprises, in which the IAs can be considered as an elementary and fundamental node and that can be enlarged to other different clusters, is fundamental to overcome the problem of small dimensions of Mediterranean SMEs and to help them to compete in the global Green Economy context. Indeed, the development of industrial networks in most parts of the world demonstrates that there are benefits attached to them and there are more opportunities that could be pursued [5]. In this approach, it is essential the cooperation between Local Authorities and public and private actors for the progress towards eco-industrial development [6], still considering the potential use of Eco - Industrial Parks by Local Authorities as a means of place promotion. Thus, eco-industrial development initiatives are seen not just as a means of increasing the eco-efficiency of participant companies, but also as a basis for a new form of local and regional development [7].

\section{CONCLUSION}

The collaboration among public and private stakeholders of IAs (companies, Local Authorities and neighbor population) is essential for the sustainability process. The cultural approach to sustainability gains more emphasis if it is considered that according to the analysis done, by a careful examination of needs and consequently an accurate area policy, with appropriate administrative facilitations and regulation relief, the industrial areas can seriously consider to improve their sustainability performances, with benefits for all.

\section{ACKNOWLEDGMENT}

The authors would like to thank all the partners of MEID project for their outstanding contribution to the project activities.

\section{REFERENCES}

[1] Towards a job-rich recovery, Communication from the Commission to the European, Parliament, the Council, the European Economic and Social, Committee and the Committee of the Regions, COM (2012) 173 final, 2012.

[2] M. Tarantini, A. Di Paolo, A. Dominici, A. Peruzzi, and M. Dell'Isola, Guidelines for the settlement and management of sustainable Industrial Areas, ISBN 88-8286-186-4, ed. Rome, IT: ENEA, 2007, ch. 4, pp. 23-80.

[3] S. A. Martin, K. A. Weitz, R. A. Cushman, A. Sharma, R.C. Lindrooth and S.R. Moran, "Ecoindustrial parks: a case study and analysis of economic, environmental, technical and regulatory issues", Final Report. RTI Project Number 6050 FR. Prepared for Office of Policy, Planning and Evaluation. US EPA, Washington (DC), 1996.

[4] Online database of Best Available Techniques (BAT) in the industrial areas of the Mediterranean region, MEID project. [Online]. Available: http://www.medmeid.eu/the-project/results-and-deliverables/bat-datab ase/.

[5] Guía de edificación ambientalmente sostenible, Edificios industriales, en la Comunidad Autónoma del País Vasco, $2^{\text {nd }}$ ed., Ihobe (Basque Environmental Protection Agency) and Sprilur (Basque Public Industrial Management Agency), Basque Country, E, 2012.

[6] A. Agarwal and P. Strachan, "Literature review on eco-industrial development initiatives around the world and the methods employed to evaluate their performance/effectiveness," Report for databuild, The Robert Gordon University, 2006.

[7] P. Deutz and D. Gibbs, "Eco-industrial development and regional structuring: Industrial Ecology or marketing tool?" presented at the Reinventing Regions in the Global Economy conference, Regional Studies Association, Pisa, Italy, April 12 -15, 2003.

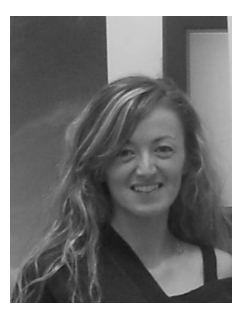

Arianna Dominici Loprieno holds a Bachelor in Environmental Engineering from the University of Bologna. Since 2004 she has been working at the Italian National Agency for New Technologies, Energy and Sustainable Economic Development (ENEA) at the Life Cycle Assessment (LCA) and Ecodesign Laboratory of the Technical Unit for Environmental Assessment Models, Methods and Technologies (UTVALAMB). She has been involved in many activities aimed at reducing the environmental impact of processes and products such as application of LCA methodology, definition of environmental criteria for Green Public Procurement (GPP) of construction materials and elements, Industrial Ecology and the development of a sustainable approach to the management of industrial areas. At present, she is working on the MEID (Mediterranean Eco Industrial Development) project and, on behalf of Italian Ministry for the Environment, she is involved in a technical working group on GPP of building materials and elements.

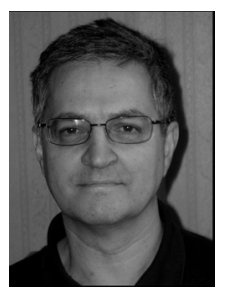

Mario Tarantini is Research Director at the Italian National Agency for New Technologies, Energy and Sustainable Economic Development (ENEA). Graduated in Mechanical Engineering, he has worked since 1984 in Energy Systems Department of ENEA and, more recently, in the Environmental Assessment Technical Unit

He has promoted since several years the development, application and dissemination of evaluation and design methods and tools, such as Ecodesign and Life Cycle Assessment (LCA) methodologies and Environmental Management System 
(EMS) procedures, for reducing the environmental impact of processes and products. He has more than 15 years of experience in conducting national and international research projects. At present, he is coordinating the MEID project and, on behalf of Italian Ministry of Environment, a working group to define environmental criteria for Green Public Procurement of building materials and elements. He planned and conducted conferences, seminars, workshop and courses on LCA for universities and industry. He has more than 50 publications and presentations at international conferences and seminars.

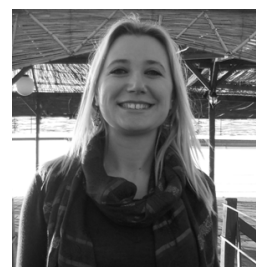

Rovena Preka is a researcher at the Italian National Agency for New Technologies, Energy and Sustainable Economic Development (ENEA). She holds a degree in Business Economics, a Master degree in Economics and Cooperation and a Phd in International Cooperation and Sustainable Development Policies at the University of Bologna (Italy). Her research is mainly connected to sustainable development issues with a special focus on environmental certification, sustainable agriculture practices and sustainable industrial areas. Recently she has been involved in research connected to Life Cycle Costing and Cost Analysis. She has worked on a number of international research projects, and is currently involved in the MEID project.

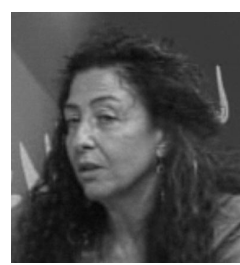

Maria Litido is Research Director at the Italian National Agency for New Technologies, Energy and Sustainable Economic Development (ENEA). Graduated in Mathematics, she is responsible for promotion and diffusion of Environmental Certifications towards regional industries and Local Authorities. She is the Scientific Responsible for Environmental LECOP Research Laboratory of Industrial Research Tecnopoli Network in Emilia-Romagna Region (Italy) and she is the lead person of MEID project. She represents ENEA at the Steering Committee of Tecnopoli Network for LECOP Research Laboratory, at the Environmental Commission of UNI (Italian Organization for Standardization) in the Environmental Management Systems Group and at the Transparency Committee of ICIC, Italian Certification Organism. 